\title{
Measuring The Impact Of Enterprise Resource Planning (ERP) Systems On Shareholder Value
}

John J. Morris, Kansas State University, USA

\begin{abstract}
ERP systems emerged in the 1990s as a tool to integrate business processes and improve productivity. Prior studies have used surveys, field studies, and event studies to measure the impact of ERP systems finding mixed results. Motivated by these mixed results this study extends this prior research by using capital markets research methods and models to measure the impact of ERP systems on shareholder value. The study examines long-term buy-and-hold returns and share prices for a sample of 145 firms from 33 industry groups that implemented ERP systems from 1994 to 2003. The results provide evidence that firms implementing ERP systems achieve abnormal returns for the first five years after implementation. Price regression models support these results finding that share prices are positively associated with ERP implementation.
\end{abstract}

Keywords: Enterprise Resource Planning; ERP; Long-Horizon Returns; Shareholder Value

\section{INTRODUCTION}

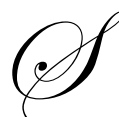

oftware vendors promote ERP systems based on their ability to improve productivity by reducing redundant processes, streamlining operations, breaking down silos of information, and providing fast and accurate information throughout the organization so that management can make faster, better decisions. To the extent that these factors lead to improved productivity and firm performance, they should manifest themselves in the form of increased profitability. This increased profitability should lead to higher dividends and/or re-investment of retained earnings, which should in turn lead to increased shareholder value.

Since their introduction in the early 1990s, these systems, which are very expensive and difficult to implement, have given rise to numerous cost/benefit research questions in both the academic and practitioner communities. Accounting Information Systems (AIS) researchers have used different approaches to measure the impact of these systems with mixed results. Some have used survey data or field studies to assess user satisfaction [1-3]. Others have used traditional accounting/financial metrics such as ROA, ROI, inventory turnover, etc. [4-7]. Still others have used stock market and financial analyst reactions to ERP investment announcements [8, 9]. One could argue that all these approaches use different proxies to measure the impact of ERP investments on firm value. Management routinely makes capital investments expecting the investments to benefit shareholders through improved firm value. Therefore, the ultimate measure of any corporate investment should be the impact it has on shareholder value. This study extends these prior research streams by using methods and models developed in the capital markets literature to more directly measure the impact of ERP systems on shareholder value.

Although Hayes et al. [8] examine the short-term impact on share price through the use of event study methodology, this study posits that long-horizon buy-and-hold returns are a more appropriate metric because ERP systems are long-term investments. Long-term buy-and-hold investors better represent the beneficiaries of an ERP system than the short-term traders that exploit gaps in information asymmetry to generate returns. This study uses a sample of 145 firms from 33 industry groups that implemented ERP systems between 1994 and 2003. The results show that average returns for ERP implementers are significantly higher than benchmark returns based on the value weighted index of the stocks in the Center for Research in Securities Prices (CRSP) database over each of the five- 
years following implementation. By contrast, returns for the three year period prior to and including the implementation year were not significantly higher than the benchmark returns. A multivariate regression analysis covering the ten year period of time surrounding implementation supports these initial findings with additional evidence that improvement in shareholder value is associated with implementation of ERP systems.

This research contributes to academic literature in two ways. First, it adds to the value of prior capital markets research by extending the application of this knowledge beyond the walls of accounting and finance. Second, it adds value to AIS research by incorporating analytical techniques from the capital markets field into the AIS literature. It also contributes to the professional community, specifically accounting and information systems practitioners, by further exploring the value creation of technology investments, independent of software vendor sponsored research and sales pitches.

The remainder of this paper is organized as follows: the next section summarizes prior research and develops a hypothesis, the third section describes the methodology used, the fourth section explains the data selection process, the fifth section presents empirical results, and the final section concludes.

\section{PRIOR RESEARCH AND HYPOTHESIS DEVELOPMENT}

Accounting and finance academics have developed an extensive body of research over the past 40 years related to capital markets. Researchers have explored the relationship between financial data and shareholder value by developing and testing various theories, models and methodologies beginning with Modigliani and Miller's [10] theory of investment and Ball and Brown's [11] linkage of accounting data to stock price. These methods and models have been used extensively in the area of accounting and finance to explain various phenomena such as: market efficiency [12], post-earnings announcement drift [13-16], abnormal returns through portfolio strategies [1720], abnormal accruals [21-26] and residual income [20,27-29] to name just a few. In spite of this rather large body of work, these methods and models have not been widely used outside the fields of accounting and finance. Other areas of academic research could benefit from expanded use of these techniques to broaden our understanding of general business issues.

Ohlson [27], and Feltham and Ohlson [28] provide a foundation for using the stock market as a proxy for the intrinsic value of a firm. The efficient market hypothesis holds that the price of a security is an accurate estimate by the market of its true value, fully reflecting all information that is publicly available [30]. Although there is debate in the academic community as to which form of efficiency the market reflects in the short-term (i.e. strong, semi-strong, or weak), there is evidence that in the long-run, the market is efficient [31]. Therefore, the market price of a firm's stock should include anticipated future residual income based on information that becomes publicly available. It follows that as benefits from an ERP system are realized, and the market becomes aware of these benefits, the value of the improvements will be included in the stock price.

Measuring this change in price is one way to assess the impact that ERP systems have on shareholder value. Another measure is the total returns experienced by shareholders based on the change in price (capital appreciation) as well as dividends earned over a period of time. Capital markets researchers use both price and returns to measure shareholder value. Kothari and Zimmerman [32] examine price models (stock price regressed on earnings per share) and return models (returns regressed on scaled earnings variables), finding that earnings response coefficients are less biased in price models, but return models have less serious econometric problems.

Many accounting and finance researchers using return models focus on short-term returns, measuring cumulative abnormal returns (CAR), usually over a three day window surrounding some event. A number of these "event studies" seek to exploit timing differences and short-term market inefficiencies to generate abnormal returns [13-18]. This methodology has also been used by researchers in the information technology (IT) field [e.g. 33, 34] and was used by Hayes et al. [8] to measure the reaction of the market to announcements made by firms that were implementing ERP systems. They use standardized cumulative abnormal returns (SCAR) over a three day window, and find an overall favorable reaction to the announcements. 
This concept of abnormal returns assumes that the market correctly predicts the impact of the event because, based on the efficient market hypothesis, the stock price adjusts to information fully within a narrow window of a few days [35]. This may be true for single announcement type events, but in the case of an ERP system, the actual event takes much longer to occur than one day and the benefits are realized over many future periods. Also, since firms make public disclosures of earnings at least quarterly, and analysts provide forecast information even more frequently, it is reasonable to assume that each of these disclosures provide implicit additional information about the impact of the ERP investment that was unknown on the date the original announcement was made. Therefore, one could argue that the appropriate measurement period for this type of event will last for many months, or even years, rather than just a few days.

An alternative method of measuring shareholder returns is to measure long-horizon buy-and-hold returns. Easton et al. [36] argue that the association between returns and earnings are stronger over longer intervals, because value relevant events occurring before and during the return interval have a better chance of being incorporated in the explanatory earnings variable as the window is expanded.

This longer-horizon approach is especially appropriate for ERP systems, which represent major investments expected to improve earnings over a long-term horizon, with an understanding that short-term earnings may even suffer during the implementation process. Assuming ERP systems provide a competitive advantage, as advertised by ERP vendors, one would expect that this competitive advantage would manifest itself in the form of increased residual income. This increased residual income will lead to either increased dividend payouts or increased stock prices reflecting the reinvestment of earnings back into the firm, both of which will impact shareholder returns over a long-horizon. This leads to the following hypothesis stated in the alternative form:

Hypothesis: Implementation of Enterprise Resource Planning (ERP) systems will have a positive impact on shareholder value.

\section{METHODOLOGY}

The following long-term buy-and-hold model from Ang and Zhang [35] is used to calculate abnormal returns for initial testing of the hypothesis:

$A R_{i t}=R_{i t}-B R_{i t}$

Where $A R_{i t}$ is the abnormal return for firm $i$ in year $t, R_{i t}$ is the long-term buy-and-hold return for firm $i$ in year $t$, and $B R_{i t}$ is the long-term buy-and-hold return for a benchmark of firm $i$ in year $t$. Individual returns are monthly holding period returns obtained from the CRSP database cumulated for each firm's fiscal year. The CRSP value weighted index is used for benchmark returns. Abnormal returns are examined for each of the ten years surrounding the implementation event using a t-statistic to test the null hypothesis that the mean buy-and-hold abnormal returns are equal to zero versus the alternative hypothesis that they are greater than zero.

The following multivariate price regression model, adapted from Ohlson [27], is used to test the difference between abnormal returns before and after ERP implementation:

$P_{R I C E_{i t}}=a+\beta_{1} I M P_{i t}+\beta_{2} E P S_{i t}+\beta_{3} B V P S_{i t}+\beta_{4} B U L L_{i t}+\varepsilon_{i t}$

Where:

$P R I C E_{i t}=$ Price per share for firm $i$ four months after fiscal year end $t$

$I M P_{i t} \quad=$ Dichotomous variable set to (1) for each of the five fiscal years following implementation and (0) for the implementation year and each of the four years prior to implementation for firm $i$

$E P S_{i t} \quad=$ Earnings per share for firm $i$ for fiscal year $t$

$B V P S_{i t} \quad=$ Book value per share for firm $i$ as of fiscal year end $t$

$B U L L_{i t}=$ Dichotomous variable set to (1) during bull market years (1990-99 \& 2004-06) and (0) during bear market years (2000-03 \& 2007-09) 


\section{DATA SAMPLE}

A sample of 145 firms representing 33 industries that implemented ERP systems between 1994 and 2003 is used to test the hypothesis. Table 1 provides a breakdown of these firms by SIC code and implementation year. The majority of the sample is made up of manufacturing firms that implemented systems from 1997 to 2001 . The sample selection process begins with the 91 ERP announcements made between 1994 and 1998 from Hayes et al. $[8]^{1}$, from which 36 firms were eliminated because they are no longer listed or data are otherwise not available. This initial sample is extended by searching available newswire services using the Lexis-Nexis service for years after 1998, searching on key phrases such as: "ERP", "Enterprise Resource Planning", and "Enterprise Systems." This search found an additional 90 firm announcements yielding a total of 145 firms for which return data are available for at least two years following implementation in the CRSP database. In some cases the announcements do not contain specific implementation dates or time lines. In those cases, judgment was used to determine which year best represents the implementation year ${ }^{2}$. Firm specific data is based on each firm's fiscal year, with accounting data as of the end of the fiscal year from Compustat, and market data as of the end of the fourth month following the end of the fiscal year from CRSP ${ }^{3}$. This approach, which is common in accounting research, helps to ensure that the market has the latest fiscal year-end accounting information available to incorporate in the share price.

Table 1: ERP Firms by Two Digit SIC Code and Implementation Year

\begin{tabular}{|c|c|c|c|c|c|c|c|c|c|c|c|}
\hline 2 Digit SIC Codes & 94 & 95 & 96 & 97 & 98 & 99 & $\mathbf{0 0}$ & $\mathbf{0 1}$ & $\mathbf{0 2}$ & $\mathbf{0 3}$ & Total \\
\hline 01-Agricultural Production Crops & & & & 1 & & & & & & & 1 \\
\hline 13-Oil and Gas Extraction & & 1 & & 1 & 3 & 2 & 1 & & & & 8 \\
\hline 16-Heavy Construction & & & & & & & & 1 & & & 1 \\
\hline 20-Mfg: Food and Kindred Products & & & 2 & 1 & & 2 & 1 & 1 & 1 & & 8 \\
\hline 23-Mfg: Apparel & & & & & 1 & 1 & 1 & & & & 3 \\
\hline 24-Mfg: Lumber \& Wood Products & & & & & 1 & & & & & & 1 \\
\hline 25-Mfg: Furniture \& Fixtures & & 1 & & & 2 & 1 & & & & & 4 \\
\hline 26-Mfg: Paper \& Allied Products & 1 & & & 1 & & 1 & 1 & & & & 4 \\
\hline 27-Mfg: Printing \& Publishing & & 1 & 1 & 1 & & & & 1 & & & 4 \\
\hline 28-Mfg: Chemicals & & 1 & 1 & 2 & 2 & 1 & 3 & 2 & 3 & 2 & 17 \\
\hline 29-Mfg: Petroleum Refining & & & & 1 & & & & & & & 1 \\
\hline 30-Mfg: Rubber \& Misc. Plastic & & & & & & 1 & & & & & 1 \\
\hline 33-Mfg: Primary Metal Industries & & & & 1 & & 1 & & 1 & & & 3 \\
\hline 34-Mfg: Fabricated Metal Products & & & 1 & & & 1 & 1 & & & & 3 \\
\hline 35-Mfg: Ind. \& Com. Machinery & & 1 & & & 5 & 8 & 2 & 4 & 1 & 1 & 22 \\
\hline 36-Mfg: Electronic \& Elect. Equip. & & & 1 & 2 & 5 & 3 & 3 & 4 & & & 18 \\
\hline 37-Mfg: Transportation Equipment & & 1 & 1 & & 1 & & 1 & 1 & & & 5 \\
\hline 38-Mfg: Measuring \& Control Instr. & & 1 & & 2 & 1 & 1 & 1 & 2 & 1 & 1 & 10 \\
\hline 39-Mfg: Misc. Manufacturing & & & & & & 1 & & & & & 1 \\
\hline 42-Motor Freight Transportation & & & & & & 1 & & & & & 1 \\
\hline 45-Transportation by Air & & & & & 2 & & & & & & 2 \\
\hline 48-Communications & & & & & 1 & & 1 & & & & 2 \\
\hline 49-Electric, Gas \& Sanitary Services & & & & & & & & & 2 & & 2 \\
\hline 50-Wholesale: Durable Goods & & & & & & 2 & & & & 1 & 3 \\
\hline 51-Wholesale: Non-Durable Goods & & & & & & & 1 & & & & 1 \\
\hline 52-Retail: Bldg Materials, Hardware & & & & & & 1 & & & & & 1 \\
\hline 54-Retail: Food Stores & & & & & 1 & & & & & & 1 \\
\hline 59-Retail: Miscellaneous & & 1 & & & 2 & 2 & & & & & 5 \\
\hline 63-Insurance Carriers & & & & & & 1 & & & & 1 & 2 \\
\hline 67-Holding \& Other Investment & & & 1 & 1 & & & & & & & 2 \\
\hline 73-Automotive Repair \& Service & & & & 1 & & 2 & & 3 & & & 6 \\
\hline 80-Health Services & & & & & & 1 & & & & & 1 \\
\hline 87-Engineering, Actg., R\&D, Mgt & & & & & & & & & 1 & & 1 \\
\hline Totals & 1 & 8 & 8 & 15 & 27 & 34 & 17 & 20 & 9 & 6 & 145 \\
\hline
\end{tabular}

${ }^{1}$ I would like to thank David C. Hayes and Jacqueline L. Reck for providing this list of firms

${ }^{2}$ As an example, if the announcement is made early in the fiscal year indicating that an implementation has been recently completed, then the prior year is used, or if the announcement is made in the middle of the year indicating that an implementation will be taking place, then the following year is used.

${ }^{3}$ For instance firms with a calendar fiscal year would have accounting data as of December $31^{\text {st }}$ and market data as of April $30^{\text {th }}$. 


\section{EMPIRICAL RESULTS}

Figure 1 provides a graphic view of abnormal returns over the ten year period surrounding ERP implementation. The pattern shows an increase following the implementation year $(t)$ that peaks in year $t+2$ at $27.5 \%$, then declines each year thereafter to $12.7 \%$ by year $t+5$. The pattern also shows that in the implementation year $(t)$ and the two years prior to implementation $(t-1$, and $t-2)$ abnormal returns were $5 \%$ or less.

Figure 1: Abnormal Returns for ERP Firms vs. CRSP Value Weighted Index

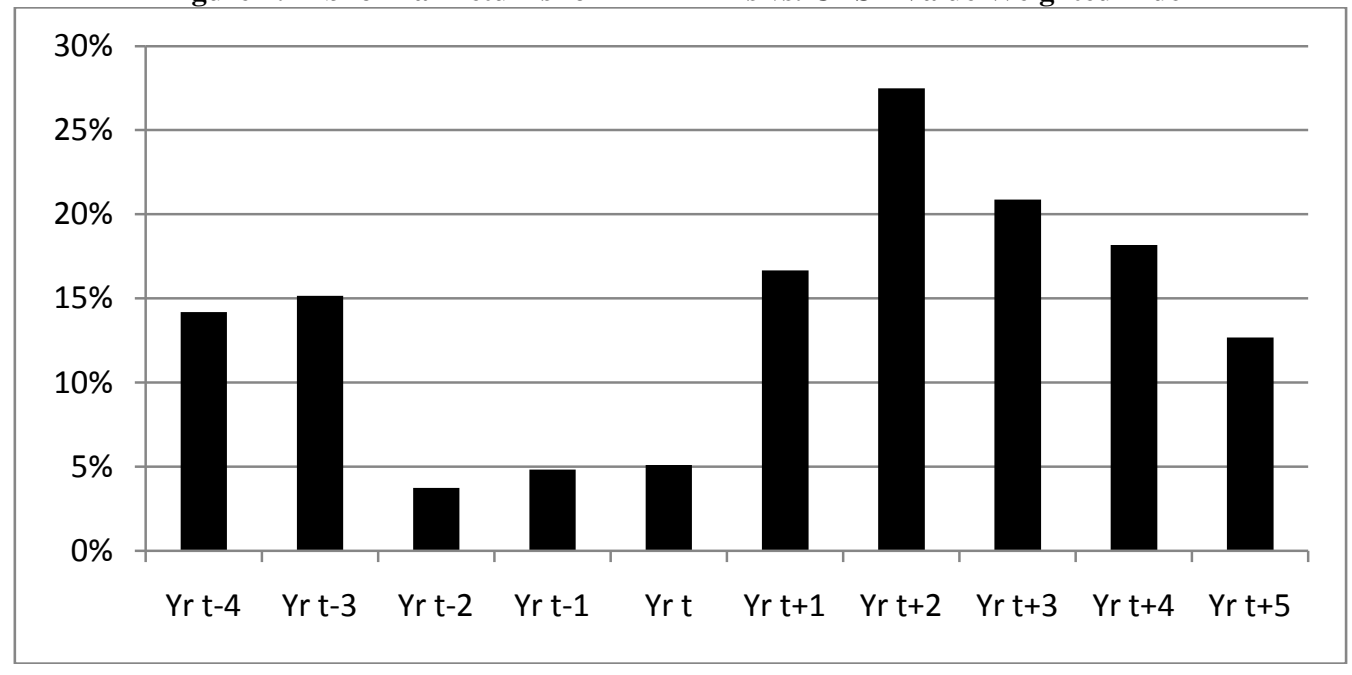

Table 2 provides additional details for these returns, including t-statistics indicating that abnormal returns for the implementation year and the two years prior to implementation were not statistically different from zero. By contrast, the abnormal returns in all five years following implementation are statistically significant. These results provide initial support for the hypothesis indicating that implementation of ERP systems has a positive impact on shareholder value as measured by long-term buy-and-hold returns.

Table 2: Abnormal Returns for ERP Firms vs. CRSP Value Weighted Index

\begin{tabular}{cccccc}
\hline Year & N & $\begin{array}{c}\text { ERP Firm } \\
\text { Average Return }\end{array}$ & $\begin{array}{c}\text { CRSP Value } \\
\text { Weighted Index }\end{array}$ & $\begin{array}{c}\text { Abnormal } \\
\text { Return }\end{array}$ & t-statistic \\
\hline t-4 & 118 & 0.3554 & 0.2135 & 0.1419 & $1.96 * *$ \\
t-3 & 121 & 0.3485 & 0.1968 & 0.1517 & $1.61 *$ \\
t-2 & 134 & 0.2426 & 0.2051 & 0.0375 & 0.80 \\
t-1 & 138 & 0.1989 & 0.1506 & 0.0483 & 0.63 \\
t & 142 & 0.1831 & 0.1319 & 0.0512 & 0.96 \\
t+1 & 145 & 0.2290 & 0.0624 & 0.1666 & $1.90 *$ \\
t+2 & 145 & 0.3136 & 0.0388 & 0.2748 & $1.50 *$ \\
t+3 & 143 & 0.2390 & 0.0302 & 0.2088 & $2.20 *$ \\
t+4 & 139 & 0.2523 & 0.0706 & 0.1817 & $3.40 * *$ \\
t+5 & 133 & 0.2063 & 0.0795 & 0.1268 & $2.91 * * *$ \\
\hline
\end{tabular}

$*, * *, * * *$ indicates significance at $.10, .05, .01$ two-tail test

Table 3 provides descriptive statistics in Panel A and a correlation matrix in Panel B for variables used in the multivariate regression model. Average price for the sample is $\$ 33.27$ per share, with average earnings per share of $\$ 1.40$ and book value per share of $\$ 14.42$. Significant correlations between independent variables occur between EPS and BVPS (0.8555, p<0.0001), which is expected, and (IMP) the implementation indicator variable and (BULL) the bull market variable $(-0.4687, \mathrm{p}<0.0001)$, which indicates that the post implementation period is 
The results in Table 4 show that the variable of interest (IMP) is significant at the .05 level for the total sample and marginally significant at the .10 level for the sub-sample, indicating that share price is positively associated with the ERP implementation event. As expected, the coefficients on the other independent variables are highly significant, including the control variable for the bull versus bear market effect. The F-statistics $(\mathrm{p}<0.0001)$ and the Adjusted R-Square results (0.9124 and 0.9234) indicate that the model is well specified. To address any possible heteroscedasticity problem, the t-statistics are adjusted using the White method. These results provide additional support for the hypothesis indicating that implementation of ERP systems is positively associated with share price and thus shareholder value after controlling for other factors thought to be associated with share price.

\section{CONCLUSIONS}

This study examines the impact that ERP systems have on shareholder value using long-horizon returns and share prices for a sample of firms that implemented ERP systems between 1994 and 2003. It finds evidence that these firms earned abnormal returns over the five years following ERP implementation, when using CRSP's value weighted index as a benchmark. Furthermore, when the analysis is extended to compare the five year period after implementation to the previous five years using a price regression model, it finds evidence that share prices are positively associated with the ERP implementation event. The model takes into consideration that share price over various time periods may be influenced by general market conditions by including an indicator variable to differentiate between bull and bear markets. Taken as a whole, the evidence supports the hypothesis that implementation of ERP systems has a positive impact on shareholder value.

These results should be of interest to investors, ERP vendors, and management personnel responsible for major IT investment decisions. Since these systems are very expensive to acquire and implement it would seem useful to have empirical evidence that they have a positive impact on shareholder value from a source that is not trying to sell a product or service. The results should also contribute to academic literature on capital markets and information systems by applying capital markets research methods to information systems research events. Bringing together these two academic disciplines in this manner could provide a basis for future research that uses capital market methods to address other information systems issues.

\section{AUTHOR INFORMATION}

Dr. Morris is an Assistant Professor of Accounting in the College of Business Administration at Kansas State University in Manhattan Kansas. Prior to earning his Ph.D. at Kent State University with a major in accounting and a minor in information systems, he had an 18 year career in accounting and financial management followed by eight years of consulting focused primarily on ERP systems implementation.

\section{REFERENCES}

1. Themistocleous, M., et al. ERP Problems and Application Integration Issues: An Empirical Survey. in 34th Hawaii International Conference on System Sciences. 2001. Hawaii.

2. Umble, E., R. Haft, and M. Umble, Enterprise Resource Planning: Implementation Procedures and Critical Success Factors. European Journal of Operations Research, 2003. 146(2): p. 241-258.

3. Bradford, M. and J. Florin, Examining the Role of Innovation Diffusion Factors on the Implementation Success of Enterprise Resource Planning Systems. International Journal of Accounting Information Systems, 2003. 4: p. 205-225.

4. Poston, R. and S. Grabski, Financial Impacts of Enterprise Resource Planning Implementations. International Journal of Accounting Information Systems, 2001. 2(4): p. 271-294.

5. Nicolaou, A.I., Firm Performance Effects in Relation to the Implementation and Use of Enterprise Resource Planning Systems. Journal of Information Systems, 2004. 18(2): p. 79-105.

6. Hitt, L.M., D.J. Wu, and X. Zhou, Investment in Enterprise Resource Planning: Business Impact and Productivity Measures. Journal of Management Information Systems, 2002. 19(1): p. 71-98.

7. Hunton, J.E., B. Lippincott, and J.L. Reck, Enterprise Resource Planning: Comparing Firm Performance of Adopters and Nonadopters. International Journal of Accounting Information Systems, 2003. 4(3): p. 165184. 
8. Hayes, D.C., J.E. Hunton, and J.L. Reck, Market Reaction to ERP Implementation Announcements. Journal of Information Systems, 2001. 15(1): p. 3-18.

9. Hunton, J.E., R.A. McEwen, and B. Wier, The Reaction of Financial Analysts to Enterprise Resource Planning (ERP) Implementation Plans. Journal of Information Systems, 2002. 16(1): p. 31-40.

10. Modigliani, F. and M.H. Miller, The Cost of Capital, Corporation Finance and the Theory of Investment. The American Economic Review, 1958. XLVIII: p. 261-297.

11. Ball, R. and P. Brown, An Empirical Evaluation of Accounting Income Numbers. Journal of Accounting Research, 1968. 6(2): p. 159-178.

12. Beaver, W.H., The Information Content of Earnings. Journal of Accounting Research, 1968. 6(Supplement): p. 67-92.

13. Bernard, V.L. and J. Thomas, Evidence that Stock Prices do not Fully Reflect the Implications of Current Earnings for Future Earnings. Journal of Accounting \& Economics, 1990. 13(December): p. 305-340.

14. Bernard, V.L. and J. Thomas, Post-Earnings Announcement Drift: Delayed Price Response or Risk Premium? Journal of Accounting Research, 1989. 27(Supplement): p. 1-48.

15. Freeman, R. and S. Tse, The Multiperiod Information Content of Accounting Earnings: Confirmations and Contradictions of Previous Earnings Reports. Journal of Accounting Research, 1989. 27(Supplement): p. 49-79.

16. Abarbanell, J. and V.L. Bernard, Tests of Analysts' Overreaction/Underreaction to Earnings Information as an Explanation for Anomalous Stock Price Behavior. The Journal of Finance, 1992. 47(July): p. 11811207.

17. Fama, E.F., Efficient Capital Markets II. The Journal of Finance, 1991. 46(December): p. 1575-1617.

18. Fama, E.F. and K.R. French, The Cross-Section of Expected Stock Returns. The Journal of Finance, 1992. 47(July): p. 427-465.

19. Dechow, P. and R. Sloan, Returns to Contrarian Investment Strategies: Tests of Naive Expectations Hypothesis. Journal of Financial Economics, 1997. 43(January): p. 3-27.

20. Frankel, R.M. and C.M.C. Lee, Accounting Valuation, Market Expectation, and the Cross-Sectional Stock Returns. Journal of Accounting \& Economics, 1998. 25(June): p. 283-319.

21. Sloan, R., Do Stock Prices Fully Reflect Information in Accruals and Cash Flows About Future Earnings? The Accounting Review, 1996. 71(July): p. 289-315.

22. Jones, J., Earnings Management During Import Relief Investigations. Journal of Accounting Research, 1991. 29: p. 193-228.

23. Dechow, P., R. Sloan, and A. Sweeney, Causes and Consequences of Earnings Manipulation: An Analysis of Firms Subject to Enforcement Actions by the SEC. Contemporary Accounting Research, 1996. 13(1): p. 1-36.

24. Teoh, S.H., T.J. Wong, and G. Rao, Are Accruals During Initial Public Offerings Opportunistic? Review of Accounting Studies, 1998. 3: p. 175-208.

25. DeFond, M.L. and C.W. Park, The Reversal of Abnormal Accruals and the Market Valuation of Earnings Surprises. The Accounting Review, 2001. 76(July): p. 375-404.

26. Xie, H., The Mispricing of Abnbormal Accruals. The Accounting Review, 2001. 76(July): p. $357-373$.

27. Ohlson, J.A., Earnings, Book Values, and Dividends in Equity Valuation. Contemporary Accounting Research, 1995. 11: p. 661-687.

28. Feltham, G.A. and J.A. Ohlson, Valuation and Clean Surplus Accounting for Operating and Financial Activities. Contemporary Accounting Research, 1995. 11(2): p. 689-735.

29. Penman, S.H., Financial Statement Analysis and Security Valuation. 2nd ed. 2004, New York: McGrawHill/Irwin.

30. Eakins, S.G., Finance, Investment, Institutions, and Management. 2nd ed, ed. D. Clinton. 2002, New York: Addison Wesley.

31. Fama, E.F., Market Efficiency, Long-Term Returns, and Behavioral Finance. Journal of Financial Economics, 1998. 49: p. 283-306.

32. Kothari, S.P. and J. Zimmerman, Price and Return Models. Journal of Accounting \& Economics, 1995. 20: p. $155-192$.

33. Dos Santos, B.L., K. Peffers, and D.C. Mauer, The Impact of Information Technology Investment Announcements on the Market Value of the Firm. Information Systems Research, 1993. 4(1): p. 1-23. 
34. Subramani, M. and E. Walden, The Impact of E-Commerce Announcements on the Market Value of Firms. Information Systems Research, 2001. 12(2): p. 135-154.

35. Ang, J.S. and S. Zhang, An Evaluation of Testing Procedures for Long Horizon Event Studies. Review of Quantitative Finance and Accounting, 2004. 23: p. 251-274.

36. Easton, P., T. Harris, and J.A. Ohlson, Aggregate Accounting Earnings Can Explain Most of Security Returns: The Case of Long Return Intervals. Journal of Accounting \& Economics, 1992. 15(2/3): p. 119142 . 
NOTES 